\title{
DEVELOPMENT OF TEACHERS' PROFESSIONAL COMPETENCE WITHIN EDUCATIONAL TRANSFORMATIONS
}

\section{РОЗВИТОК ПРОФЕСІЙНОЇ КОМПЕТЕНТНОСТІ ВЧИТЕЛІВ В УМОВАХ ОСВІТНІХ ТРАНСФОРМАЦІЙ}

\author{
Viktoria TARASOVA, \\ Postgraduate of the third level of \\ higher education \\ Bogdan Khmelnytsky Melitopol \\ State Pedagogical University \\ $\triangle 20$ HetmanskaSt., \\ Melitopol, Zaporizhzhia region, \\ 72300
}

\author{
Вікторія TAPACOBA, \\ здобувач третього рівня вищої \\ освіти
}

https://orcid.org/0000-0003-1250-2027 marsetka11@gmail.com

Мелітопольський державний педагогічний університет імені

Богдана Хмельницького

$\triangle$ вул. Гетьманська, 20

м. Мелітополь, Запорізька обл., 72300

\section{ABSTRACT}

Original manuscript received: October 04, 2019

Revised manuscript accepted: December 12, 2019

Socio-political and socio-economic changes that are taking place at the present stage of development of Ukraine, predetermine the strengthening of attention to the systematic development of teachers' professional competence. The change in the educational paradigm, that takes place in Ukraine, requires a revision of the approaches of professional training and retraining of teachers. The old slogan concerning the teacher as a leading figure of the educational process has disappeared from the arena, giving way to the idea of the XXI century, which proves that the teacher is "a carrier of educational and social changes". The high requirements imposed by the state to the level of professional competence of the teacher of a new formation - personality that capable of selfimprovement, self-development and creativity are constantly being improved and increased. Teachers are encouraged to systematic advanced training, the search for new, alternative directions of professional training and constant development of professional competence.

Key words: competence, competency, professional competence, professional competence of a young teacher, management of professional competence development, formation and development of the teacher, advanced training.

Актуальність проблеми. Для сучасного вчителя важливим $€$ не тільки вміння оперувати власними знаннями, а й бути готовим змінюватись та пристосовуватись до нових потреб ринку праці, оперувати й управляти інформацією, швидко приймати рішення, активно й творчо діяти, навчаючись упродовж життя. Тому, сьогодні, кажучи про якість професійно-педагогічної підготовки та перепідготовки вчителя, все 
частіше вживають поняття “професійна компетентність”. Базовий рівень професійної компетентності майбутні вчителі здобувають у педагогічних закладах вищої освіти, а подальше становлення і розвиток відбувається в процесі професійної діяльності, це зумовлює необхідність управління цим процесом з боку адміністрації загальноосвітніх навчальних закладів. 3 огляду на постійні зміни в освіти питання розвитку професійної компетентності вчителів весь час знаходяться в колі уваги науковців.

Мета статті. Розглянути сутність поняття "професійна компетентність" та особливості їі становлення в процесі професійної діяльності вчителя, виявити сутність, а також суб'єкти та форми управління процесом її формування в умовах закладу загальної середньої освіти.

Теоретичні основи. Теоретичною основою нашої роботи є вітчизняні та зарубіжні наукові розвідки з проблем дослідження та розвитку професійної компетентності вчителів. Так, стратегії фрормування професіоналізму вчителів відображено в дослідженнях вітчизняних науковців О. Дубасенюка, Г. Кучерявого, Л. Хомича, Л. Хоружої. Проблеми професійної діяльності вчителя знайшли своє відображення у працях І. Беха, Н. Бібік, І. Зязюна, В. Мадзігона, Л. Мітіної, О. Мороза, О. Пєхоти, В. Радула, О. Пометун, О. Савченко, О. Сухомлинської та ін. Дослідженням проблеми підвищення та розвитку професійної компетентності вчителя займалися М. Елькін, С. Клепко, М. Лук'янова, О. Овчарук, О. Онаць, Л. Паращенко, С. Сисоєва, Т. Сущенко, Л. Хоружа, Н. Чепурна та ін. Важливі чинники, що сприяють розвитку професійної компетентності вчителів, досліджено в працях Л. Даниленко, Г. Єльнікової, Н. Клокар, В. Маслова, Є. Павлютенкова та ін. Актуальними для дослідження управління розвитком професійної компетентності вчителя є праці, в яких висвітлено особливості управління школами нового типу (В. Бондар, Л.Даниленко, Л. Калініна, Н. Островерхова, Л. Паращенко); психологічні основи управління школою (Л. Карамушка, Н. Побірченко); управління науково-методичною роботою в закладах загальної середньої освіти (І. Жерносек, Н. Кнорр, О. Остапчук); підвищення професійної кваліфікації вчителя (В.Базуріна, Т.Браже, О.Варецька, Б. Жебровський, І. Зязюн, Н. Ничкало, В. Олійник, С. Сисоєва); професійна адаптація вчителя (А. Василюк, О. Мороз).

Результати. Національною стратегією розвитку освіти на період до 2021 року визначено, що освітні процеси в Україні мають відповідати сучасним суспільним змінам, сприяти трансформаційним перетворенням, підвищувати якість навчання на інноваційній основі, розвивати наукову та інноваційну діяльність тощо. Особистісно-професійна компетентність педагога $€$ необхідною умовою його професійного зростання в умовах інноваційних змін. Концептуальною моделлю професійної компетентності вчителя, яка відтворює характеристики професійно сформованого вчителя як ідеальну мету, виступає освітній стандарт педагогічної освіти.

Загальна феноменологія професійної компетентності вчителя знайшла відображення у великій кількості психолого-педагогічних досліджень і має достатньо широкий спектр трактувань. Розкриваючи сутність та зміст складного та багатовимірного поняття "компетентність", 
більшість дослідників розглядають його як оцінювальну категорію діяльності людини, яка має такі характеристики: розуміння суті виконуваних завдань, знання, досвід у цій сфрері та активне його використання, почуття відповідальності, вміння обирати засоби, адекватні конкретним обставинам, здатність успішно виконувати завдання, що належать до її компетенції.

Словник сучасної англійської мови визначає компетентність (з лат. competens - належний, відповідний) як сукупність необхідних якостей щодо ефективної професійної діяльності,систематичних функціональних знань й умінь (науково-виробничих, суспільно-політичних, психологопедагогічних, економічних, предметних і відповідних особистісних якостей) (Можаєва, 2009).

В Українському Радянському Енциклопедичному словнику (за ред. А. Кудрицького) компетентність (з лат. узгодження, поєднання) трактується як коло повноважень особи, питань, з яких ця особа має певні знання та досвід. Укладачі "Стратегії модернізації змісту загальної середньої освіти" під компетентностями розуміють здатність особи здійснювати складні культуро доцільні види дій і наголошують, що цей феномен охоплює головні складові освіти: когнітивну, технологічну, мотиваційну, етичну, соціальну та поведінкову, містить низку однорідних чи близьких умінь і знань, що належить до широких сфрер культури та діяльності.

Вчені Н. Радіонова та А. Тряпіцина розглядають професійну компетентність учителя як інтегральну характеристику, що визначає здатність розв'язувати проблеми й типові професійні задачі, які виникають у реальних ситуаціях професійної педагогічної діяльності з використанням знань, професійного й життєвого досвіду, цінностей та нахилів.

На думку О. Пометун, діяльність людини, зокрема засвоєння будьяких знань, умінь і навичок, передбачає конкретні дії, операції, які виконує людина. Виконуючи дії, розмірковуючи над їх виконанням, усвідомлюючи потребу в них та оцінюючи їхню важливість для себе та суспільства, людина розвиває власну компетентність у тій чи іншій сфері її діяльності.

Отже, компетентність - наявність знань, умінь, навичок, що відображаються в теоретично-прикладній підготовленості до їх реалізації в діяльності на рівні функціональної грамотності, натомість "компетенція" передбачає наявність досвіду самостійної діяльності на основі цих знань, умінь і навичок. Отже, компетентність - це результат навчання, а компетенція - це комплексність у дії.

Слід наголосити, що хоча компетентнісний підхід $€$ відбиттям євроінтеграційних та глобалізаційних процесів у науці та освіті, на сьогодні не існує термінологічної єдності щодо розуміння його найважливіших понять. Так, значна частина вітчизняних науковців розмежовують поняття “компетентність" і “компетенція", що в англомовних джерелах визначається єдиним словом - "competence". Це не може не позначитися на якості перекладних текстів? та не ускладнити певним чином? їх інтерпретацію.

Тому частина українських та російських дослідників (Л. Болотов, В. Леднев, М. Нікандров, М. Рижаков) підкреслюють саме практичну 
спрямованість компетенцій, які розуміють як сферу відносин, що існують між знанням і дією в людській практиці. Обидва поняття розглядаються як тотожні - як здібність робити щось добре чи ефективно; відповідність вимогам, що висуваються під час працевлаштування; здібність виконувати особливі трудові функції (згідно з тлумаченням Європейського фонду освіти).

Інші дослідники А. Хуторський, С. Шімов, І. Агапов, І. Зимня, Н. Кобзар диференціюють поняття "компетентність" і “компетенція", визнаючи компетентність складною характеристикою особистості. Так, компетенція розглядається як заздалегідь створена вимога до навчальної підготовки того, хто навчається, характеристика його професійної ролі, а компетентність - ступінь відповідності цій вимозі, рівень засвоєння компетенції, особистісна характеристика людини. Щодо професійної підготовки, то “компетенцію” розглядають як базову якість освітньої підготовки спеціаліста, а "компетентність" - як результат такої підготовки, прояв компетенції. За лапідарним визначенням І. Зимньої, компетентність - актуальний прояв компетенції, це інтелектуально й особистіснообумовлений досвід соціально-професійної діяльності людини, знання, на базі яких людина може використовувати компетенції.

Розвиток професійної компетентності молодих учителів розпочинається під час навчання у закладах вищої освіти, а продовжується у професійній діяльності на робочих місцях. Сучасний учитель повинен постійно професійно розвиватися. Цей процес $є$ довготривалим, “пов'язаним з удосконаленням професійної діяльності і забезпеченням якісної освіти учнів". Так, фахівці повинні мати уявлення про соціальну значимість свого виду праці, шляхи та засоби її реалізації; розвинуте почуття професійної гідності та відповідальності. Поняття “професійна компетентність молодого вчителя" розглядається як інтегральне утворення, що репрезентоване системою теоретичних знань, практичних умінь, соціально значущих і професійно важливих якостей особистості, сформованої мотиваційноціннісної сфери та набутого досвіду, діалектичний взаємозв'язок яких забезпечує результативність його професійної педагогічної діяльності.

Педагогічна діяльність учителів у закладах загальної середньої освіти починається із входження в професію, що складається 3 трьох етапів: ознайомлення з вимогами до професійної діяльності в цьому закладі освіти, - на цьому етапі молоді вчителі ретельно вивчають нормативно-правові документи, які регламентують діяльність навчального закладу та кожного його суб'єкта, визначають завдання освітнього процесу; встановлення відповідності між рівнем готовності молодого вчителя до виконання професійних завдань та вимогами до професійних обов'язків молодих учителів цього навчального закладу - на цьому етапі представниками адміністрації проводяться різноманітні заходи з метою отримання первинної інформації щодо рівня їх готовності до виконання професійних функцій; подолання труднощів на початку педагогічної діяльності. На цьому етапі молодих учителів залучають до практичної діяльності різного змісту, а саме: викладання предметів, класного керівництва, завідування навчальним кабінетом, ведення гуртків. 
Протягом названих етапів відбувається професійна адаптація вчителя - складний, багатоплановий процес оволодіння професією і пристосування до ії вимог; формування гнучкої соціально-професійної позиції в системі формальних і неформальних стосунків в освітній організації, досягнення учителем належного рівня професійного розвитку. Н. Островерхова та Л.Даниленко виділяють такі стадії професійної адаптації вчителя початківця, що відбуваються протягом входження його в професію: соціально-педагогічну адаптацію (терміном до одного року), соціально-професійну ідентифікацію (до трьох років) та соціальнопрофесійну стабілізацію (до п'яти років).

Управління розвитком професійної компетентності вчителя, за визначенням О. Онаць, у контексті здійснення ним педагогічної діяльності це процес визначення стратегії i тактики досягнення заданого кваліфрікаційного рівня, прогнозування професійного зростання і самоствердження. Професійно компетентним можна назвати вчителя, який на достатньо високому рівні здійснює педагогічну діяльність, педагогічне спілкування, досягає стабільно високих результатів у навчанні та вихованні учнів. Розвиток професійної компетентності - це розвиток творчої індивідуальності, фрормування можливості сприйняття педагогічних новацій, здібностей адаптуватися у мінливому педагогічному процесі.

В Україні на сьогодні існує певна система управління розвитком професійної компетентності учителів, ланками якої є заклади загальної середньої освіти, науково-методичні центри, інститути післядипломної педагогічної освіти, управління та відділи освіти, методичні кабінети. В умовах закладу загальної середньої освіти суб'єктами цієї системи є керівник навчального закладу, його заступники, шкільний психолог, голови шкільних та районних методичних об'єднань, творчих груп, учителі-методисти (наставники), кожний з яких розв'язує коло питань, які перебувають у межах його компетенції.

Організація управління розвитком професійної компетентності учителів здійснюється як у традиційних фрормах (школа молодого вчителя, стажування, наставництво, педагогічний лекторій, бесіди, консультування, педагогічні майстерні, тематичні семінари і конференції тощо), так і у інноваційних (тренінги, майстер-класи, педагогічні десанти, клуби молодих учителів, методичні дебати, професійні конкурси, проекти тощо).

Професійна компетентність вчителя - інтегральне утворення, що репрезентоване системою теоретичних знань, практичних умінь, соціально значущих і професійно важливих якостей особистості, сфрормованої мотиваційно-ціннісної сфери та набутого досвіду, діалектичний взаємозв'язок яких забезпечує результативність його професійної педагогічної діяльності. Ї̈̈ розвиток розпочинається в молодих учителів під час навчання у закладах вищої освіти, а продовжується й удосконалюється під час здійснення ними профресійної діяльності на робочих місцях. Процес входження в професію здійснюється у кілька етапів, зміст і тривалість яких варіюється й визначається змістом і організацією роботи з молодими вчителями.

Управління розвитком професійної компетентності вчителя - це 
процес визначення стратегії і тактики досягнення заданого кваліфікаційного рівня, прогнозування професійного зростання і самоствердження. В Україні на сьогодні склалась досить розгалужена, поліінституційна система управління розвитком професійної компетентності учителів, суб'єктами якої в умовах закладів загальної середньої освіти директор, його заступники, шкільний психолог, голови методичних об'єднань та творчих груп, учителіметодисти (наставники), кожний з яких розв'язує коло питань, які перебувають у межах його компетенції. Отже, саме керівник закладу має створити умови, які сприяють у підвищенні рівня професійних компетентностей учителів: предметної, методичної, комунікативної, інформаційної, загальнокультурної, правової. Основними шляхами реалізації цих завдань - це залучення вчителя до процесу безперервної освіти; праця у творчих або проблемних (динамічних) групах; інноваційна діяльність, участь у фахових конкурсах професійної майстерності, майстер-класах, форумах, навчання на дистанційних курсах; узагальнення й розповсюдження власного професійного досвіду; підвищення кваліфікації; розвиток професійної компетентності через активні форми роботи з іншими педагогами.

Висновки. Саме тому в умовах запровадження інноваційних процесів в освіті функція професійного розвитку вчителів має обов'язково реалізуватися в науково-методичній роботі в міжкурсовий період, що вимагає освоєння, упровадження і відпрацювання педагогічних ідей, ефективного досвіду, моделювання змін в організації освітнього процесу в закладі загальної середньої освіти.

\section{Література}

1. Кобзар Н.В. Поняття “компетентність”, “компетенція” і “готовність до діяльності” в сучасній освітній парадигмі. - Науковий вісник Донбасу. Електронне наукове видання. - 2010- № 3 (11) - Режим доступу: http://almamater.Inpu.edu.ua/magazines/elect v/NN11.pdf

2. Компетентнісний підхід у сучасній освіті: світовий досвід та українські перспективи: Бібліотека з освітньої політики / Під заг. ред. О.В.Овчарук. - К.: „K.I.C.”, 2004. - 112c.

3. Ляшенко О.І. Пріоритети розвитку української школи в умовах реформування освіти / О. І. Ляшенко // Педагогічна освіта: теорія і практика : зб. наук. пр. Кам'янець Подільського нац. ун-т ім. Івана Огієнка. - Кам'янецьПодільський, 2016. - Вип. 22. - С. 39-42.

4. Можаєва О.М.Формування і розвитокосновних компетентностей особистостівпочатковійшколі / О.М. Можаєва // Початкова освіта. - 2009. - № 32. - С. 9-13.

5. Онаць О.М. Практика фрормування професійної компетентності молодого вчителя // Шлях освіти. / О.М.Онаць. - 2005. - №3. - С. 34-39.

6. Педагогічна майстерність / І.А. Зязюн, Л.В. Крамущенко, І.Ф. Кривонос та ін. / За ред. І.А. Зязюна. - 2-ге вид., допов. і переробл. - К.: Вища школа, 2004. - 422 с.

7. Пільова С.Г. Визначення сутності понять "компетентність" і “компетенція" в сучасній педагогіці / С.Г. Пільова // Личность в образовательном пространстве: сб. науч. статей. - Запорожье, 2010. - Ч. 1. - С. 141-143.

8. Сисоєва С.О. Основи педагогічної творчості: підручник / С. Сисоєва. К. : Міленіум, 2006. - 344 с.

9. Яланська С. П. Психологія розвитку педагогічної творчості: Навчальний посібник / С. П. Яланська, Т.С. Пільгук - Полтава : ПНПУ імені В.Г. Короленка, 2015. -138 c. 


\section{References}

1.Kobzar, N.V. (2010). Poniattia "kompetentnist", "kompetentsiia" i "hotovnist do diialnosti" v suchasnii osvitnii paradyhmi [The concept of "competence", "competency" and "willingness to work" in the modern educational paradigm]. Electronic Scientific Specialized Edition Naukovyi Visnyk Donbasu, 3(11) Retrieved from http://almamater.Inpu.edu.ua/magazines/elect v/NN11.pdf

2.Liashenko, O.I. (2016). Priorytety rozvytku ukrainskoi shkoly $v$ umovakh reformuvannia osvity [Priorities of the development of Ukrainian school in the context of educational reform]. Pedahohichna osvita : teoriia i praktyka - Pedagogical education: theory and practice: A collection of scientific works of Kamyanets Podilsk Ivan Ohiyenko National University. (Vols. 22), (pp. 39-42) [in Ukrainian].

3. Mozhaieva, O.M. (2009). Formuvannia i rozvytok osnovnykh kompetentnostei osobystosti v pochatkovii shkoli [Formation and development of basic competencies of the individual in primary school]. Pochatkova osvita - Primary education, 32, 9-13 [in Ukrainian].

4.Onats, O.M. (2005). Praktyka formuvannia profesiinoi kompetentnosti molodoho vchytelia [Practice of formation of professional competence of the young teacher]. Shliakh osvity, (3), 34-39 [in Ukrainian].

5.Ovcharuk, O. V. (Ed.). (2004). Kompetentnisnyi pidkhid u suchasnii osviti: svitovyi dosvid ta ukrainski perspektyvy: Biblioteka z osvitnoi polityky [Competence approach in modern education: world experience and Ukrainian perspectives: Library of educational policy]. Kyiv: K.I.S. [in Ukrainian].

6.Pilova, S.H. (2010). Vyznachennia sutnosti poniat «kompetentnist» i «kompetentsiia» v suchasnii pedahohitsi [Definition of the essence of the concepts of "competence" and "competency" in modern pedagogy]. Lychnost $v$ obrazovatelnom prostranstve - Personality in the educational space: A collection of scientific works, (pp. 141-143) [in Ukrainian].

7.Sysoieva, S.O. (2006). Osnovy pedahohichnoi tvorchosti [Fundamentals of pedagogical creativity]. Kyiv: Milenium [in Ukrainian].

8. Yalanska, S. P. (2015). Psykholohiia rozvytku pedahohichnoi tvorchosti: navchalnyi posibnyk [Psychology of the development of pedagogical creativity: a manual]. Poltava: Poltava V.G. Korolenko National Pedagogical University [in Ukrainian].

9.Ziaziun, I.A., Kramushchenko, L.V., \& Kryvonos, I.F. (2004). Pedahohichna maisternist [Pedagogical craftsmanship]. (I.A. Ziaziun, Ed.) (2nd ed.). Kyiv: Vyshcha shkola [in Ukrainian].

\section{АНОТАЦІЯ}

Суспільно-політичні й соціально-економічні зміни, що відбуваються на сучасному етапі розвитку України, зумовлюють посилення уваги до систематичного розвитку професійної компетентності вчителів. Вітчизняна освітня парадигма вимагає перегляду підходів професійної підготовки та перепідготовки учителя, адже “... зійшло з арени старе гасло про вчителя як про провідну фрігуру навчально-виховного процесу, поступившись місцем ідеї XXI cm.: вчитель - це носій освітніх і суспільних змін". Високі вимоги, що висуваються державою до рівня профресійної компетентності педагога нової формації, особистості, здатної до самовдосконалення, саморозвитку й креативності, постійно підвищуються. Вони спонукають учителів до систематичного підвищення кваліфікації, зумовлюють пошук нових, альтернативних напрямів профресійної підготовки та постійного розвитку фрахової компетентності.

Ключові слова: компетентність, компетенція, професійна компетентність,профресійна компетентність молодого вчителя, управління розвитком професійної компетентності, становлення і розвиток вчителя, підвищення кваліфрікації. 